\title{
THE POLITICS OF VIGILANCE IN SOUTH-EASTERN NIGERIA
}

David Pratten

\section{INTRODUCTION}

This paper argues that governance can be best analyzed within modes of vigilance. Where recent work on the post-colonial state has emphasised the symbolic and practical constitution of the state through surveillance and spatialization, so in counterpoint, this analysis illustrates that social engagement with the state is based on conceptions of vigilance and practices of counter-surveillance with both spatial and temporal dimensions. Drawing on an ethnography of Annang youth associations in south-eastern Nigeria, this analysis outlines how the micro-politics of vigilance are based on knowledge of the states' patrimonial 'ways of operating' and processes which define internal, localized rights, registers and styles of action. This argument is based on an analysis of popular responses to disorder which contribute to an 'insurgent' construction of the public realm in which groups marginalized and excluded challenge the logic and constructions of the public good.

It is limiting to argue that African politics can be summed up in only two concepts, rents and predation, yet these are nevertheless important features of the social and political landscape, especially in a rentier polity of low taxes and patronage such as Nigeria (Barber 1982; Forrest 1986; Watts 2003). Rents and predation, in fact, have particular qualities that shape an inherent duality to everyday meanings of the state. Recent observations on the postcolony identify this duality in the creative tensions that emerge from a set of oppositions in which the state is both 'illusory and concrete; distant and localized; personal and impersonal; violent and destructive as well as benevolent and productive' (Hansen \& Stepputat 2001: 5). In this understanding therefore forms of state intervention may be repressive and resisted while others are more benign and may be desired and demanded. The institutions of governance in contemporary Nigeria share this duality and are both instruments of political domination in local communities (predation) and means for allocating patronage (rents) (Vaughan 1995: 502). In response, vernacular notions of governance are shaped along these two axes - by the opportunities afforded through the 
instrumentalization of distribution and by necessity in the face of the insecurities of instrumentalized disorder. On one axis, the politics of distribution, people organize themselves within familiar frameworks to 'capture' the state. On the other, discourses on disorder, law and order, social practices are mobilized as a response to and a protection against the state.

How political operators control or transform the postcolonial African state on behalf of specific, local economic and social groups is a question that has been framed within a number of discursive registers the domestication and banalization of excess and largesse (Mbembe 1992, 2001), the 'politics of the belly' (Bayart 1993), the 'instrumentalization of disorder' (Chabal \& Daloz 1999), the 'criminalization of the state' (Bayart et al. 1999), and the 'moral matrix of family and food' (Schatzberg 1993, 2002). Each offers powerful concepts in understanding the dynamics and positivity of personalized patrimonial modes of governmentality. These vernacular notions of governance are premised on the definition of regimes of power in an imaginative complicity between rulers and ruled, patrons and clients. Overall, these perspectives stress consumption, achievement, and winning.

While the value systems and cultural codes which allow a justification of 'criminalisation' and 'corruption' by those who practise it need to be explored, the focus of these works, however, has led to an impasse in intellectual debate about the characterization of the African state. In part, attempts to understand the legitimisation of 'illicit practices' within socio-cultural logics are rendered problematic because they are prone to generalisation and tend to ignore the specificities of local historical narratives (Hagberg 2002). In part also, the cultural logic of impunity represented in these recent works is dependent on highly individualist conceptions of the state and of political action, and emphasize the role of leaders and 'big' men at the expense of the lives, politics and collective actions of ordinary people (Mustapha 2002). It is necessary, therefore, to examine the tactics of those who have yet to win and to study localized struggles against criminalization and disorder in their proper social and cultural context. Recent examples which shift the focus onto public accountability include Hagberg's (2002) analysis of the Burkinabe protest movement, Trop c'est trop ('Enough is Enough'), and Kelsall's (2003) comparison of cursing and financial auditing as forms of verification in northern Tanzania.

Following Mitchell's insight, it is argued that political subjects and their modes of resistance are formed as much within the organizational terrain of the state, rather than in some wholly exterior social space (1991: 93). Modes of collective action operate within the contours and fault lines of this landscape, not outside it. Nigerian nonstate groups have sought, through their claim-making, to reach an accommodation and to insert themselves within patrimonial lines of 
state re-distribution. Fears and aspirations of the state are not focused on a monolithic, bureaucratic structure, but of a set of procedures, state offices and processes through which personal power is exercised in political conflict and competition. Individuals and collective groupings therefore engage with a diverse and heterogeneous set of institutions of the Nigerian nation state, and in this context the instability of its norms, laws and institutions, make it a privileged site for negotiation, bargaining and brokerage (Olivier de Sardan 1999). The forms of social organization that concern us here do not confront or press up against the state authority from below but are rather 'contemporaries of the organs of the state - sometimes rivals, sometimes servants, sometimes watchdogs, sometimes parasites, but in every case operating on the same level' (Ferguson 1997: 59).

To grasp these local manoeuvres we require an alternative analytic to that based on the disciplines of domination and the techniques by which governable spaces and subjects are manifested (Rose 1999: 32; Ferguson \& Gupta 2002). To focus on modes of domination or the 'problematics of repression', as de Certeau refers to them, is to underplay the political agency of ordinary people:

The privilege enjoyed by the problematics of repression in the field of research should not be surprising ... But this elucidation of the apparatus by itself has the disadvantage of not seeing practices which are heterogeneous to it and which it represses or thinks it represses. Nevertheless, they have every chance of surviving this apparatus too, and, in any case, they are also part of social life, and all the more resistant because they are more flexible and adjusted to perpetual mutation. When one examines this fleeting and permanent reality carefully, one has the impression of exploring the night-side of societies, a night longer than their day, a dark sea from which successive institutions emerge, a maritime immensity on which socioeconomic and political structures appear as ephemeral islands. (Certeau 1984: 41)

From this perspective it is possible better to understand the heterogeneous practices through which ordinary people survive by wit and improvisation, practices that are necessarily obscured from the glare of repressive governmental apparatus. Our attention, therefore must focus on an analysis of what de Certeau alludes to here as the 'night-side of societies'. I take this to represent something akin, in the African context, to what Worby (1998: 564) describes as a 'gray zone' and what Lund (2001: 845) refers to as 'twilight' to describe the ambiguous, shadowy quality of institutions and individual motivations that populate the political landscape.

Michel de Certeau's insights can further illuminate the micropolitical processes by which people 'make' postcolonial modes of governance and 'make do' in the face of their disorder. For this a mode of analysis is required that firstly champions the agency of ordinary people, and secondly illustrates the complexity, plurality, temporality 
and improvisation of their actions. It is in this context that de Certeau's theoretical framework is especially helpful in coming to terms with the practice of governance since his analysis shows how the 'weak' make use of the 'strong' and create for themselves a sphere of autonomous action and self-determination.

From the breadth of de Ceteau's work, his comments on the concept of the 'tactic' are of particular note. A 'tactic', de Certeau states, is a calculated action, an 'art of the weak' whose hallmark is vigilance:

[A tactic] takes advantage of 'opportunities' and depends on them, being without any base where it could stockpile its winnings, build up its own position and plan raids. What it wins it cannot keep. This nowhere gives a tactic mobility, to be sure, but a mobility that must accept the chance offerings of the moment, and seize on the wing the possibilities that offer themselves at any moment. It must vigilantly make use of the cracks that particular conjunctions open in the surveillance of the proprietary powers. It poaches them. It creates surprises in them. It can be where it is least expected. It is a guileful ruse (Certeau 1984: 37)

Tactics are determined by the absence of power. They must play on and within a terrain imposed upon them and therefore manoeuvre 'within the enemy's field of vision' (Certeau 1984: 37). An important distinction is drawn here between strategies and tactics and between their use of space and time. Unlike the strategies of those in power which concern the definition and occupation of spaces of power, tactics occupy an ambiguous space. They are defined by the absence of a 'proper locus'. Rather, tactics depend on a clever utilization of time. De Certeau therefore distinguishes between the two ways of operating, the strategies of the strong, and the tactics of the weak, according to whether they 'bet on place or on time' (Certeau 1984: 39). Overall, the significance of this analytical framework rests on the ideas of vigilance and the monitoring of opportunities. In the context of this ethnography it is through vigilance and vigilantism that Annang youth secure niches of profit and protection within a patrimonial mode of governance in Nigeria.

This paper is based on research in southern Nigeria, in Annang communities in Ukanafun Local Government Area of Akwa Ibom State. It focuses mostly on the headquarters of the local government in the village of Ikot Akpa Nkuk. Here Annang youth groups contest power through complex and ambiguous conceptions of accountability which draw on idioms of monitoring and surveillance, screening and vigilance. These repertoires of accountability operate within a framework of implied or explicit violence and at various opportunistic nodes of re-distribution. Hence, within these spheres youth groups have presented various responses including vigilantism, screening political candidates, monitoring local government expenditure, checking the award of compensation payments to local chiefs, 
threatening contractors and para-statals to complete development programmes, and monitoring price controls. These modes of vigilance and accountability are configured by internal imperatives as much as they are by the national and transnational political economy. They are intimately associated with the elaboration of constituencies and their localized rights of political contest and action. And, above all, they are about enforcing localized cultures of accountability that are shaped epistemologically by concepts of the person - especially the patron and the thief.

Vigilance concerns the definition of cognitive, temporal and spatial boundaries. It concerns the protection and care of the community encompassed within these boundaries, and it involves maintaining surveillance and taking action against threats to this community. Vigilance is most obviously associated with vigilantes and vigilance committees, groups who take the law into their own hands, and indeed Nigerian vigilante groups will figure in this narrative. However, the actions of youth associations more generally are also configured in a wider mode of 'civic vigilance'. In this sense also, the contemporary politics of vigilance concern contests over responsibilities and functions that further blur the boundaries of the state. Several examples of this mode of 'civic vigilance' at work in Nigeria illustrate the broad range of tactics that are adopted by ordinary people as they 'make do' in the postcolony. Critically these tactics concern the deployment of 'insider' knowledge of procedures of the state, counter-surveillance, and the (re)imagining and mobilization of communities and constituencies. Crucially also these examples also illustrate that modes of accountability assume many forms, spaces and times.

Writing over a decade ago Jane Guyer (1992) analyzed the local implications of the Nigerian oil boom and the political and economic centralization it fuelled on the modes of engagement between society and state. She argued that where local government had been downgraded, where resources were not generated locally from taxation, and where policy implementation at the local government level was highly dependent on central state subsidy, the material basis for 'liberal' democratic struggles for accountability and control were more or less defunct. As a result, she argued, people engaged with the state through other means:

In a situation where the official government system does not impose a framework for thinking about - legitimating, resisting, reconceptualizing - the relevant units in, and the shifting shape of, inequality within and between communities and levels of the social hierarchy then some other moral framework and modus vivendi develops for dealing with wealth and power originating in the corporate sector (Guyer 1992: 69).

These means were especially linked to securing and making claims on public office which is seen as an imperative if unpredictable link to 
corporate, central sources of finance and which in turn give rise to modes of clientelism and prebendalism which dominate the Nigerian political landscape. State functions, in turn, become fractured as the functions of local government are replaced by and linked to office holders, chieftaincy and private organizations.

This process, Guyer argued, resulted in instability and a formal organizational complexity with overlap and gaps that demanded the constant vigilance and involvement of the people, especially of elites, to keep their collective as well as sectional and personal interests represented (69). Guyer (1992: 68) therefore pointed to a locus of labour-intensive engagement between what she framed as the corporate and non-corporate sectors. This labouring was most pronounced among the rural elite and self-styled youth leaders, people themselves no better off than small scale farmers or traders, many of whom were living on pensions. Combinations of these characters routinely engaged in party political mobilization and addressed 'public' issues, especially in transition periods and in the lead up to elections.

It is the vigilance and involvement of local elite and the youth associations they lead (what Guyer refers to as 'the discrete overwork of the bourgeoisie') that more recent analyses have dealt with in the context of violence in the Niger Delta. Michael Watts, for instance, has shown how the political logic of local, ethnic claims-making serves to 'fragment, pulverise, and discredit the state and all of its forms of governance' and that in its stead factional struggles and militant particularisms have emerged each attempting to establish order (Watts 2003: 17-20). Illustrating this point through an example of relations between the Nembe community in the southern Delta and the Shell oil company during the 1990s, Watts shows that in order to subvert the chief's monopoly on oil company compensation payments, youth groups were established by local political figures with insider knowledge of how to manage successful claims. Their collusion with oil company liaison officers and the consequent subversion of chiefly authority was met with strategic alliances between youth and chiefs, and a growing (and armed) conflict between youth groups for access to Shell.

What emerged was a form of privatized violence, which Watts calls 'vigilante rule', involving a complex of complicities between chiefs, youth groups, local security forces, and the companies. Watts refers to this process as the overthrow of pastoral chiefly power and a thickening of civil society leading to the formation of a 'governable space of civic vigilanteism [sic.]' (Watts 2003: 20). Comparatively, therefore, this analysis appears to confirm, several of the arguments outlined here concerning the mode of civic vigilance characteristic of Nigerian micro-politics - its contests over the rights of governance, its dependence on insider information, its deployment of actual and rhetorical violence, and its operations that are complicit and internal to authority. 
Both these examples illustrate the politics of vigilance in southern Nigeria by focusing on the roles of youth patrons, youth groups and hometown associations. The politics of vigilance draw upon ambiguous conceptions of youth agency (Durham 2000; Bucholtz 2002). It is a vigilance of 'youth' in contemporary Africa that captures their political tactics, not merely as vandals but as vanguards of a public sphere whose contours are unexpected (Diouf 1996; Cruise O'Brien 1996; Ya'u 2000; Momoh 2000; Gore \& Pratten 2003). The marginality of the category of youth contributes to the dual character of its engagement in the making of patrimonial modes of governance at once innovative and creative and yet subject to cooption as clients by patrons.

Born into the interstices of colonial rule youth-led hometown associations have long sustained academic interest as a valuable lens on wider social and political processes. As such the literature on hometown associations spans a variety of topics and theoretical perspectives - urbanization (Banton 1957; Parkin 1966, 1969; Southall 1975; Gugler 1971, 1991); communal politics (Wolpe 1974; Smock 1971); rural-urban links and migration (Baker \& Pedersen 1992; Pratten 1997, 2000; Trager 1998); civil society and democracy (Barkan et al. 1991; Woods 1994); indigenous knowledge and social development (McNulty \& Mark 1996; Honey \& Okafor 1998); the 'politics of belonging' (Geschiere \& Gugler 1998), and transnational resource flows (Daum 1992; Grillo \& Riccio 2004). Each approach has stressed the continued salience of home-town identity and as such link the 'politics of improvement' (self-help projects and political representation) to the 'politics of belonging' (the constantly shifting, often fragmenting construction of meaningful constituencies). Within the analysis of the African 'crisis' they are seen sometimes as part of the solution (by liberals who see them as exponents of self-help service and infrastructure providers and as agents of political accountability); and sometimes as part of the problem (as 'tribalists'). These are the 'uncool' (Comaroff \& Comaroff 2000: 22) forms of African association, kinbased and ethnic organizations which apparently fail to enter the narrowly defined institutional arena of civil society, but which have long represented an attempt to attain some form of 'accommodation with modernity' (Smock 1971: 9) Hence, they are ideally suited as windows on the contemporary night-side, grey zone and twilight of state-society engagement at the key interfaces of corruption and crime.

\section{THE POLITICS OF SQUANDERMANIA}

Corruption in the postcolony must be seen as a mode of deploying force and coercion with its own positivity (Mbembe 2001: 84 ). It is a specific mode of active control over revenue collection and the judiciary that is not simply a matter of connivance or of exploiting 
bureaucratic positions. At the same time condemnations, conversations and accusations concerning corruption are neither casual nor abstract; they must be taken seriously. They appropriate culturally embedded, localized idioms of legitimacy and accountability to stake claims and assert rights; in this way 'the threat of denunciation, or in some cases the act itself, is always to be interpreted in the context of political or factional combat' (Olivier de Sardan 1999: 49fn). Discourses of corruption therefore articulate both with the intersecting of different transnational forces and with distinctive historical trajectories (Gupta 1995: 393).

The discourse on corruption is a discourse of accountability, and as Herzfeld argues 'accountability is a socially produced, culturally saturated amalgam of ideas about person, presence and polity' (Herzfeld 1993: 47). As such 'corruption' is a marker of difference which distinguishes those with power and those without and acts to de-legitimize the provenance of wealth and power gained from engagement with or within the bureaucratic infrastructures of the nation state. Political accountability, as John Lonsdale reminds us, is part of 'the moral calculus of power; it concerns the mutual responsibilities of inequality' (1986: 128). The rhetoric of corruption marks insiders from outsiders and maps the contours and boundaries that are drawn along ethnic, regional, religious, gender, class, and rural-urban lines. The exclusionary practices of corruption and anticorruption therefore fuel a proliferation of internal borders, whether imaginary, symbolic, in economic or power struggles (Mbembe 2001: 87).

This discourse on corruption is highlighted in the trajectories of Annang collective action during the twentieth century in which hometown associations and their elite leaders have sought ethical probity in public office-holders. The self-styled progressive elite of the early colonial period in Annang society was partly made up of students of the first Qua Iboe Mission schools which were opened in the Annang hinterland in the early 1920 s and who entered colonial service by the 1930 s to become court clerks. Also 'straddling' this class were cloth traders, more successful farmers and money lenders who though illiterate had the resources to buy bicycles and therefore to travel to the District office in order to lodge petitions and protests. These were the 'A-Lights' of colonial Ukanafun, those who commissioned petitionwriters and who were feared by the court sitting members who would be ousted following the A-Lights' allegations (Pratten forthcoming). At higher echelons were the 'reading public' of the 30 and 40s, subscribers to the local newspapers, the audience at literary society debates (Newell 2001) and members of organizations who engaged with the issues of political reform at provincial, regional and national levels (Udoma 1987).

In the Annang region the dominant antecedent is the Ibibio State Union and its engagement with the provincial public sphere 
during the early 1940s. In 1941 and 1942 delegations of Ibibio Union members conducted 'enlightenment campaigns' in the Ibibio and Annang districts holding public lectures in council halls. Leading the 'subjects of instruction' of the Ibibio Union's campaign were exhortations to pay tax and oppose bribery. Anti-corruption, indeed, was a key plank in the progressives' attack on the Native Administration system and contributed significantly to the credibility of the educated elite's own claim to political legitimacy. It was the lawyers and journalists, therefore, who shaped the public sphere during the Second World War years when such anti-corruption campaigns were launched, when anti-bribery movements such as the League of Bribe-Scorners were formed, when the press monitored living conditions, and the colonial administration was most vigorously criticized for its under-investment despite the development and welfare legislation.

Comparatively, the end of the colonial era in Nigeria would appear to have marked less of a transition in the discourse of corruption than might be expected. Gupta, for instance, argues that nationalist as opposed to colonial regimes sought the kind of popular legitimacy that would enable them to act in the name of 'the people' (Gupta 1995: 389). Consequently the discourse of accountability became more visible as postcolonial states vested state bureaucrats and subjects with new rights as citizens. Yet, in both the colonial and postcolonial eras the labouring of the rural Nigerian elite at the intersections of state and society has always been intensive, and as Guyer suggested vigilance has been their common watchword.

Following Sally Falk Moore's example, the following Annang case studies examine the ways in which local social action 'has its own imperatives, and its own designs.' (1996: 602). Above all their work, in this mode of vigilance, is twofold: defining communities and monitoring their boundaries. The rhetoric of unity is especially effective and common in delimiting these boundaries. Unity is a central feature of the idiom of progress and development deployed by youth associations and they expend a considerable proportion of their energies in '... the creation and strengthening of a community and the representation of its interests to the outside world' (Lentz 1995: 397). By enclosing various communities within recognized associations, whether it be ethnic group, village, lineage, electoral ward, urban migrant network or committee of friends, necessarily excludes others. The rhetoric of unity is seen as a key ingredient in the cultural recipe for political progress. In the Annang context mboho (unity) is the principal necessity for uforo (progress) and the terms are bound together literally in the names of most contemporary associations. The rhetoric of unity for such unions, which is frequently couched in the language of common heritage, forms part of an investment in constructing corporate identity through discourse, symbol and ritual which often outweighs investment in social infrastructure (Lentz 1995: 400). 
For Annang communities the post-colonial politics of 'improvement' rest on the construction and tactical deployment of these constituencies. The vigilance of Annang youth associations in patrolling these various boundaries of belonging involve engagement with the institutions of governance and draw upon two related imperatives: political representation and accountability. The overt political mobilization of youth associations not only to secure power, but to engage in national distributive networks, is justified under the rubric of 'improvement' and progress based on this political representation (ukara idem - self-rule). At the same time, youth association strategies play on Annang conceptions of accountability. Beyond financial accounting (ekot ibat), the account one makes of oneself within Annang society is judged in performative terms on the basis of the 'achievements' acquired for one's people (se enye anam your achievements for your people). These achievements, recounted in the obituaries of big men (akamba owo) are key indicators of personal progress - ackpokpor inyene (personal wealth). Wealth begets responsibilities and it is in these aspects that one's achievements are judged in terms of sending children to study overseas; educating poor people through sponsorship; donating in church; employing people in a company; entertaining visitors; holding the peace; and being truthful and steadfast. In short, accountability is judged in patrimonial terms (Ekeh 1975; Smith 2001a).

The local government reforms of 1976 and the formation of Local Government Areas mark a significant rupture in the nature of state-society engagement in the development discourse. It is possible to chart a trajectory from this point in which south-western Annang development associations shifted their focus from community development on the basis of self-help to monitoring and petitioning for state help from local government. The characteristic features of youth association engagement with the state after 1976 are captured by a union formed in the Ukanafun district at the time called Atang Anan ('Do what you say'). As its name suggests, Atang Anan, which petitioned for compensation for the land and palm plots on which the local government headquarters were built, employed a rhetoric of public accountability to ensure Ukanafun's place in the distributive process. It also drew upon local understandings of the rights and roles of youth. The qualities by which a young man (akparawa) is distinguished is public speaking (atang iko otu - to speak words in public). As lines of patrimonial inclusion and exclusion were reproduced, this further implied screening and counter-acting the perceived excesses of successive council chairmen.

In 1985, for instance, Atang Anan's successor, the Ukanafun Youth Association, reported to the Cross River State Review Panel that, 'From 1979 to 1983 , there is no evident progress in Ukanafun due to inflated contracts, kick-backs, corruption, misappropriations and gross 
embezzlements. ${ }^{\prime 1}$ In 1986, the Federal Military Government engaged in a programme to co-ordinate community development activities and to encourage the registration of development associations under the Directorate for Food, Roads and Rural Infrastructure (DFRRI). While its projects were designed to include locally mobilized inputs, the funding formula was heavily skewed towards outside investment, and in Ukanafun, as elsewhere, DFRRI funds became subject to the 'politics of plunder'. In this context the Ukanafun Youth Association again concluded that the Chairman's actions had ruined the area's development prospects:

With ghost contracts, ghost completion certificates and ghost contract payments our Directorate for Food, Roads and Rural Infrastructure is a failure in Ukanafun. ... We envisage an empty purse for our council at his rate of squandermania. ${ }^{2}$

The pattern continued. In September 1994 the Ukanafun Youth Association called on the state military administrator to transfer 'fraudulent and dubious' senior staff of Ukanafun Local Government, including the secretary, senior technical officer (STO), and treasurer. The request was submitted, it claimed, to 'forestall impending riot and loss of life', and read as follows:

1. The STO issued fake completion certificates for unfinished jobs therefore defrauding the council of millions of Naira. The council recorded a total income of $\mathrm{N} 67.65$ million but had no project to show for it;

2. From 1990 the STO personally acquired 4 vehicles, 1 private car, a 12 bedroom bungalow worth N80o,ooo, a Lister generator, an 8" borehole with overhead tank;

3. The secretary collaborated with the Treasurer to authorise 'ghost contracts';

4. That the group were seen at the LG treasury on Saturday and are suspected of destroying documents and preparing others for presentation to the Task Force on Recovery of Public Property by Caretaker Committee of Ukanafun Council;

5. They are now resorting to the services of wizards and demonic forces. We do not yet want to take the law into our hands but we will be forced to if these wicked and heathen fellows do not leave Ukanafun immediately. ${ }^{3}$

Such rhetoric employed by contemporary youth associations has particular features of note. The threat of violence and the invocation of non-Christian religious idioms are the poles against which notions of community 'good' are contrasted, while detailed

1. Ukanafun Youth Association to Cross River State Contract Review Panel, 25 April 1985.

2. Ukanafun Youth Association to Military Governor, Cross River State, 17 April 1987.

3. Ukanafun Youth Association to Military Administrator, Akwa Ibom State, 12 September 1994, 
knowledge of personal accumulation and the techniques of state bureaucracies are the bases upon which claims are legitimated. It is a rhetoric of exposé directed at patrons and re-distributors in the patrimonial power webs including not only local government chairmen but also lineage heads and village chiefs. The construction of this imagined moral community is based on the language of legitimacy forged from progressive and Christian rhetoric and is expressed in the grievances of the 'concerned citizens' of communities across southern Nigeria.

Such debates about corruption further illustrate the modes of counter-surveillance through which people engage with the state; '... even members of the subaltern classes,' Gupta notes, 'have a practical knowledge of the multiple levels of state authority' (1995: 382). Alongside narrative types of knowledge which frame the fortune and misfortune of local politicians in terms of witchcraft pacts and the ordeals of political rivals, an intimate knowledge of local government officials is gathered on the basis of their consumption, investment, indicators of illegitimate wealth as well as the timing and routes they take to enter and leave the village to collect the monthly budget.

Beyond the instability of the politics of 'corruption' it is important nevertheless to recognize the linkages between youth associations operating in this sphere and the state. Claim-making and petition-writing concerning the accountability of public office-holders are brought into the public sphere by such groups but depend on resolution through the bureaucratic procedures of the nation state. The state is appealed to as the upholder of the law and may use its sovereign power in matters of contested rights. This by definition legitimates the state and the state's means of dealing with alleged corruption irrespective of personalized patrimonialism within it. Despite the appearance of crisis, the means by which communities respond to apparent disorder contributes to a mode of governance which is dependent on validating the procedures and disciplines of the post-colonial state. Part of the way in which the state is domesticated in everyday life, therefore, is the symbolic and practical representation of the state as a locus of arbitration and adjudication. It has very little to do with dominating or restructuring the state, but rather with influencing the course of its micro-operations. The net result of the routine and regional operation of these practices in the functioning of local institutions is that governance becomes increasingly 'porous' and fragmented (Hansen \& Stepputat 2001: 32).

As Guyer suggested times of transition, especially around elections, focus the vigilance of youth and community leaders. Electoral politics are suffused with the discourse on corruption. During the Local Government elections of 1997, for example, the result was challenged by local UNCP loyalists at the appeal tribunals thus confirming a familiar pattern in Ukanafun politics in which, '... every time the Council chairman is elected, instead of being allowed to sit 
down and design programmes to uplift the area, he is made to pass through the rigours of attending to court cases and tribunals ...' (Pioneer 12 May 1997). Formal legal proceedings over alleged electoral malpractices were instigated not by the party, however, but by the Ukanafun Youth Association (Mkparawa Ikpaisong Ukanafun). Fearing a repetition of events from 1993, when Ukanafun's vote in favour of the minority SDP party was widely seen as the reason why no commissioners or pledges of amenities were made to it, the association sought to install the 'party in power.' Thus, the Ukanafun Youth Association, led by a retired army officer and former party chairman, petitioned President Abacha against the NCPN candidate in language which highlighted perceptions that the election result had been a disaster for local development prospects:

It could be recalled that since the inception of [the chairman's] administration in Ukanafun LGA no project has been embarked upon. All the council revenues and subventions are fraudulently withdrawn, while the people are in dire need of good drinking water, roads, electricity, student bursaries and other infrastructures in the area. ${ }^{4}$

Ironically, the association's petition directly attributed this investment failure to the very process it had instigated, and to the fact that the council chairman was spending his time and the council's funds at the election tribunal since they went on to complain that 'For months now nothing is visible, all our funds of our council are diverted by [the council chairman] to prosecute election cases at tribunals. ${ }^{5}$

Election campaigns, however, are not built around political actions or statements; a campaign is a question of 'character' and the election a calculus of patrimonial reciprocity (Lund 2001: 857). Being represented by a member of a community with which one can identify, and 'having a chairman from the same place' is of paramount importance. It is in this context that youth associations 'screen' politicians before they are supported to stand for elected office. Such groups, as faction makers, are expressing their palpable potential to be co-opted but in the screening process are asserting their rights to be 'remembered' as clients. The Nkek Youth Development Association, for instance, examine a candidate's 'accountability' and reputation, they will assess his or her manifesto, what the candidate will offer to do for the group and the community, their parental family (whether they were 'greedy' or 'gossiping'), whether they have been 'insulting' or 'stubborn', and whether they have committed a crime. A decision on who to support for individual offices is then made within the association and the members sign a document or swear an oath that they will vote en bloc for the candidate they have decided upon.

4. Ukanafun Youth Association to President Sani Abacha, 23 July 1997.

5. Ukanafun Youth Association to Military Administrator, Akwa Ibom State, 21 July 1997. 
Aspects of the ways in which a culture of impunity is restricted by the tactics of Annang youth associations are illustrated in an account of political hustings in the village of Ikot Akpa Nkuk in the build up to the 2003 elections. A small meeting of the Youth/Vigilante group gathered one evening in February to receive the presentation of a councillorship candidate for the PRP party, a young apprentice welder who had recently returned home to the village from Port Harcourt. His manifesto centred on the proposed rehabilitation of a market, a long abandoned youth-sponsored initiative, and the provision of scholarships for youth. Where young people are unable to progress because their parents cannot pay school fees, scholarship programmes have a continued salience. They remain important also because of the long-standing idea that an educated 'alight' will be able to develop the area. The PRP councillorship candidate presented kaikai, a bottle of Crown 4 brandy and kola. This is a standard form of hustings and was one of a series of presentations that the aspirant had to perform in each village and to each village head and council.

While it was rather low-key and apparently innocuous meeting (since the PRP had no recognized support in Ukanafun), it caused considerable anxiety. Under an existing zoning system operating within the urban ward, it was not Ikot Akpa Nkuk's turn to present a councillorship candidate. For the sake of peace between the villages the aspirant was asked to step down. The aspirant was also challenged on the timing of his campaign, and was asked why he wanted to stand for office at that moment since he was told in one of the many Annang electoral epithets 'politics is interest - politics is personal interest.' Why would a local candidate be desperate to upset the local balance of power if it was not for a personal agenda (to 'chop' the money) and to fail to meet campaign pledges? As night fell, the tension at the little meeting was palpable and captured much of the ambivalence felt by youth operating within political circuits at all levels. Several felt it was wrong for the village mkparawa to appear to be encouraging a candidate in this way because of the problems it would cause; others were encouraging the man because of the goods and money he was presenting to them. Seen in the context of a range of tactics youth employ as vehicles for inclusion the meeting represented a common dialectic in the politics of youth expressed in the discourse on corruption - they challenge clientelism and yet demand co-option.

\section{YOUTH, TRUTH AND TRIALS}

Contemporary Nigerian vigilantism concerns a range of local and global dynamics beyond informal justice. It is a lens on the politics of post-colonial Africa, the current political economy of Nigeria, and on its most intractable issues - the politics of democracy, ethnicity and religion. Vigilantism in Nigeria has recently assumed an international profile as the so-called 'ethnic militias', which emerged after the democratic transition in 1999, each assumed vigilante operations: the 
O'odua Peoples Congress active in cities of the south-west (Akinyele 2001; Nolte 2004), the hisba in the pro-sharia northern states, and the state-sanctioned Bakassi Boys of the south-east (Baker 2002; Harnischfeger 2003; Smith 2004). The violence with which these vigilante groups have been linked, especially in the religious conflicts of 2000 and 2001, and in the lead up to the 2003 elections, has earned them censure from the international human rights community (Human Rights Watch 2002, 2003; Amnesty International 2002), attempts at prohibition by the federal government, and ongoing contests over the rights to judge and punish crimes with local authorities. Yet, since the late 1980 s, from rural lineage to urban street, the widespread growth of night guards and vigilantes has been a popular local response to theft, armed robbery and threats to village security.

The legitimation of vigilante activity has extended beyond dissatisfaction with current levels of law and order and the failings of the Nigeria Police. The way in which ordinary men and women devise and support alternate strategies to mete immediate justice or to organize vigilante groups is seen as a coping mechanism in the face of a predatory state (Chabal \& Daloz 1999). It has also been argued that a range of factors contribute to a 'political imagination' that serves to legitimate their operations. These imaginings include conceptions of the elite-status and illegitimate wealth of the criminals they target; the normalization of violence as an ethical response against disorder; and the vigilantes' symbolic status as 'superheroes' (Smith 2004). The various regional vigilante groups are also claimed to draw legitimacy from the way in which they represented ethnic militia, ready to defend the interests of their ethnic and religious communities. Here Nigerian vigilantism and the ethnic militia have been located in the context of west Africa's 'collapsed states' and what Reno calls the politics of insurgency. In particular he situates the Nigerian ethnic militia in the militarization of patronage networks that have become an endemic feature from the Guinea Coast to the Niger Delta (Reno 2002).

To understand the local legitimacy of vigilantism in postcolonial Nigeria, however, it is also necessary to recognize its internal imperatives. Vigilantism in this context is embedded in narratives of contested rights, in familiar everyday practices, understandings of personhood and knowledge and in alternate, older registers of governmentality. These are often dismissed as neo-traditional, reactionary or as a process of 're-traditionalisation' visible in a resurgence of ethnicity and ritualized violence (Chabal \& Daloz 1999: 45). This classification as neo-traditional often obscures the activities that take place within these associational forms and obscures the histories of localized idioms of power, knowledge and accountability in understanding popular responses to the instrumentalisation of disorder (Gore \& Pratten 2003: 213-14). As a consequence, it is important to discern how those who step into the void of disorder and 
de-centeredness and establish routine by knowledge and practice do so by grasping the importance of how cultural patterns are articulated to systems of political domination (Fields 1982: 593).

The popular legitimacy of vigilantism is located in a political narrative of contests for the symbolic and economic capital derived from hearing cases. Judging cases has long been an index of power in Annang society and has been contested by its key forms of individual and collective office-holding (lineage, chieftaincy, secret societies and youth association). The ways in which thieves were apprehended and punished is most directly linked to the roles and aesthetics of various secret societies (especially the ekpe leopard society) and night guards. Surveillance (ukpeme iduy, to watch village) was organised by lineage heads who picked small groups of young men to monitor paths and plots from palm-leaf constructed hides (ufok usuy). Both the guards and societies would parade thieves they had caught around the village and the market. As Austen (1986: 385) reminds us intolerable deviants in many African societies are those who threaten control over reproductive capacities expressed in terms of both access to food and the ability to procreate children. In Annang the protection of produce was paramount, and the theft of seed yams or cassava stems - for the following year's harvest - was considered abhorrent.

Partly because of these cultural frameworks the relationship between vigilantes and the colonial state was ambiguous and difficult. By the early 1940s the government opposed the ufok usum on the grounds that they had, '... developed into an organisation for demanding money with menaces. ${ }^{6}$ In colonial discourse the guards were thought to be a fruitful source of revenue for village chiefs who held illegal trials in which persons arrested by the ufok usun were forced to confess their crime. Sometimes after the thief had been shamed by being rubbed with charcoal and paraded around the market they were taken to the Native Court, tried and sentenced again. ${ }^{7}$ As a result of these reports ufok usuy were banned. ${ }^{8}$ Within a decade, however, amid persistent popular calls for their re-instatement night guards had been accommodated as part of new 'watch committees' operating alongside the rural police patrols launched in the early 1950s.9 While they met with an ambivalent response from the authorities it is clear from the symbols of these night guards that, as today, character was all important in the selection and symbolic repertoire of the Annang night guard. The lanterns that the guards carried became a mark of honesty that was appropriated in the imagery of post-war nationalist politics. ${ }^{10}$ While the NCNC were represented by

6. Acting Resident, Calabar to Secretary, Eastern Provinces, 19 May 1942, CALPROF 3/1/1957.

7. Ibid.

8. Native Authority Ordinance (No. 43), 1933, CALPROF 3/1/1957.

9. Annual Report, Calabar Province, (C. J. Mayne), 1952, MSS Afr.S.1505.6.

10. QIM Quarterly, January 1958, (76), D/3301/EA/27. 
the symbol of the cockerel and the Action Group by the palm tree, independent Annang political candidates used the hurricane lantern in their campaigns during the 1950 s as a sign of their good character.

Fears of armed robbery in Ukanafun during the late 1990s were founded on reports of unprecedented violent crime rates. Cities across the south-east were caught in the grip of a crime-wave. Calabar was reported to be under siege by armed robbers who raided petty traders' premises by night (Pioneer 12-18 May 1997). A spate of 'dare-devil' armed robberies in Enugu led the state military administrator to accuse the police and traditional rulers of complicity with the criminals (Punch 29 August 1997). Owerri and Onitsha witnessed full-scale riots when ritual killers were found in possession of body parts (Smith 2001b). And, a rapid increase in the crime rate in Port Harcourt in late 1996 was crudely calculated in the deaths of armed robbers in gunbattles with Police (Tide 17 November 1996).

Fear of renewed crime-waves were heightened in Akwa Ibom after a spate of armed robberies in Uyo (Pioneer 12-18 May 1997), and as a result of renewed 'underworld activity', the Akwa Ibom State Police Commissioner criticised local government councils for failing to fund the local police effectively, and called on communities to mount vigilante patrols (Post Express 3 November 1998). This request echoed that of the Paramount Ruler of Ukanafun Local Government who had proposed a resolution in the Traditional Rulers' Council in August 1996 that each village should be responsible for the formation of a vigilante committee." The Akwa Ibom State Administrator's concern at the increasing rate of armed robbery in the state led him to remind traditional rulers in April 1997 to report any suspected criminals or 'strange faces' in their domains (Punch 28 April 1997). In Ikot Akpa Nkuk the youth association, Mboho Ade Uforo Ikot Akpa Nkuk (MUKAN - 'Unity for Progress'), for example, formed security patrols called 'vanguards' in 1988. Their responsibilities were defined as follows:

1. Every member of the Association is empowered to arrest and interrogate anybody caught stealing or suspected to have stolen and report them straight to the Police.

2. Mount routine patrols at markets to check for suspects and stolen goods

3. Those caught buying stolen goods will be reported to the village council and to the Police.

4. Mount road blocks at night in some streets in the village to trap thieves. ${ }^{12}$

Despite official encouragement the relationship between vigilantes and the Police is contested. Their role places vigilante groups

11. Minutes of the Ukanafun Traditional Rulers Council meeting, 20 September 1996.

12. MUKAN Memorandum, 9 December 1988. 
in an ongoing conflict over judicial authority between themselves, the Police and the traditional rulers. Vigilante actions, punishments and judgments, even in concert with the Police and formal judicial channels exclude the chiefs, and youth associations in some villages have deliberately avoided dispute settlement for the reason that 'This is how the chiefs 'eat' and they would not permit it.' Chiefs accuse vigilantes of complicity in personal vendettas and like all parties involved in informal tribunals are open to allegations that criminals have bribed them for their freedom. Accommodations are reached, however, as the provision of effective justice constitutes an overriding performative criteria for contemporary Annang village chiefs. ${ }^{13}$

Contemporary vigilantism represents the articulation of claims to a set of rights based on the historical and spiritual legitimacy of young powerful men, 'sons of the soil', defending the community under the protection of local religious injunction and protection. The development of hisba committees in northern states draws upon a religious idiom of legitimacy and discipline. Murray Last (2002) argues that it is a grassroots response to the failures of the judicial system and to the inequalities experienced by those young men who invoke piety as a political act and join vigilante groups to enforce the sharia code. In southern Nigeria vigilantism draws on the pervasive idiom of the secret society. Insa Nolte's (2004) work, for instance, has shown how in Yoruba communities in south-western Nigeria the membership of the Oro secret society and local vigilante groups of the O'odua People's Congress overlap. Annang vigilantism draws its legitimacy from similar performative repertoires.

The various practices that Annang vigilantism embraces combine to draw cognitive and spatial boundaries. These boundaries crucially divide good from bad, insiders from strangers, and vigilantes from thieves (Heald 1986a). For many years the vigilante force in the village of Ikot Akpa Nkuk constituted around a dozen night guards each of whom was a man of power (ockpochong - having been tested). This exclusive basis for recruitment to the vigilante group has now become an inclusive principle. Now any young man who has lived in the village for at least two years should be registered as a youth/vigilante group member. Any young man who refuses to join the vigilantes falls under suspicion as being among those 'insiders' (owo mbia) who are thought to invite armed robbers to the village and locate their sites for ambush and routes for escape. As a result the vigilante group has grown in size with about one hundred vigilantes guarding the village each night. As such active membership of the

13. Heald's analysis of the relationship between chiefs, vigilantes and the police in 196os Uganda is informative in this respect. The chieftaincy, undergoing a crisis of legitimacy and authority, co-operated with the vigilantes so that they might gain respect from both the police and their villages for handing over thieves to the authorities, thereby increasing their authority by gaining influence over a clandestine police force (Heald 1986b). 
vigilante group itself has come to constitute the boundaries of community.

Each night at ten o'clock the vigilante patrol meets at the youth association chairman's compound to announce the beginning of the nightly curfew. De Certeau's idea that subaltern tactics must cleverly manipulate time is of crucial relevance here. The vigilantes and their curfew define both physical and temporal spaces. The curfew creates a niche within the police's daily routines, and it marks a time after which the character of a person who transgresses is immediately suspect. Time is important for vigilantes in other ways too. The vigilante group routinely sits as an informal tribunal, hearing domestic and land cases, and has become popular because it costs relatively little to bring a case and because unlike lineage or village meetings, which gather on particular market days, it can meet most evenings usually after work. The funding of the vigilantes is also linked, in part, to an innovative use of time. In addition to business levies, the vigilantes are funded by the commission taken from drivers operating taxi services from the village's motor park. The rights to collect commission have long been contested as the National Union of Road Transport Workers (NURTW) runs the motor park from Monday to Saturday. The village youth, however, have recently secured a time, each Sunday, when young men from each lineage take turns to access this resource.

After the curfew is announced around a dozen vigilantes dressed in black, some disguised as women, set out into the darkness in single-file to traverse the village's boundaries. The patrol encounters small groups of fellow vigilantes at various checkpoints along the main paths that run inside and around the village. The course taken maps a topography that is a physical space and a landscape of names, a genealogical history (McCall 1995: 259; Ferme 2001: 23-48). More than this, however, the night patrol's route marks an alternative spatiality which maps a set of resonant spatial practices whose meanings and control are beyond the grasp of the state (De Certeau 1984: 93). Markets, crossroads and boundary paths are each traversed by the vigilantes in a practice reminiscent of the annual performances of ekpo (ancestral) masqueraders. During the ekpo season masked players march and sing along the boundary paths that defined an ekpo cluster thereby mapping out the political landscape of the ekpo leaders and the relationships between them. The most significant and dangerous of the vigilante checkpoints is at a junction on the villages' boundary. As the frontier against intruders and thieves it is a potent spot especially as it was the site at which war medicines (ibok ekong) were prepared for the village's founders. Hushed greetings with the dozen or so guards at the junction who are sit on felled palm trunks blocking the roads are interrupted by the firing of guns into the air. Several of the patrol team have homemade six-shooter pistols, small and poorly machined devices that are awkward to hold, and unpredictable to use. Firing a gun not only serves as an audible deterrent and an indication of their physical protection. It also serves as a sign that the vigilantes 
have significant spiritual protection and are the 'rightful' persons (unen owo) to defend the village.

In addition to mapping temporal and spatial communities in which young men are vested with the rights to exercise justice, the legitimacy of Annang vigilantism is assessed within cultural frameworks of accountability linked to conceptions of agency, personhood and power and the oppositions this produces between vigilantes and thieves. The most distinctive interpretative clue in this context is the opposition in the character of Annang ancestors (ekpo) between good spirits, those who were successful, and bad ones, those who were unsuccessful or notoriously malicious. These categories were linked both to the status of the living person and the form of their death; a normal death ( $m k p a$ ) was contrasted with a sudden or violent one (afai). This opposition expresses a common contrast in Annang belief between the right-hand, associated with respect, authority, truth and good character, and the left, linked to disrespect, wrong-doing and malevolence The right/left, good/bad opposition also corresponds to the aesthetic expression of concepts of beauty (eti) and ugliness (idiok). These terms are ways of relating character (eti ilo, good person, idiok ilo, bad person) and behaviour (eti usuy, good way, idiok usuy, bad way). The aesthetic representations of personhood are captured at their most figurative in the ancestral masquerade (ekpo) and in its use of beautiful and ugly masks.

Of all the masked figures who perform at the season's end in October (ndok), the ekpo ndem masquerade is the most disfigured, ugly, anti-human, unpredictable and malevolent spirit. ${ }^{14}$ It is a threat to security, fertility and the progress of the community. During its performance it is painted with charcoal, and is restrained by a rope tied at the waist. When apprehended a thief is handled in much the same way - they are stripped naked, painted with charcoal, a palm frond is hung around their neck and they were paraded around the village and neighbouring markets tied at the waist. The practice by which a thief is symbolically represented as a malevolent, anti-social threat to order and fertility like ekpo ndem points to the extent of the fear associated with thieves and armed robbers. These ideas are confirmed in other ways too. Ekpo ndem (of all masquerades) is associated with preparation in the bush (where initiates eat only raw food) and, as a result, with the most complete sense of spiritual embodiment (Picton 1990: 195). Symbolically thieves and armed robbers are also associated with dangerous, anti-social locations such as hiding in the bush, and with ambivalent, internalized forces since a thief is said to be possessed by a 'stealing spirit' (spirit ino) in which they enter an altered consciousness (inam) and 'do not know themselves again.'

14. The sight of ekpo ndem is relatively rare these days, but its practices are still familiar. Children's masquerades, for instance, mimic its performance in plays of their own in which young boys parade a cloth-covered figure tied at the waist to demand 'dashes' from passers-by. 
Annang informal justice is popular not only because it inflects these registers of personhood, but also because it employs practices, 'rituals of verification', which establish truth, guilt and accountability through public spectacle and performance. Performance is central to Annang concepts of knowledge and oaths (mbiam) and ordeals (ukaj) are the key performative devices through which people may determine truth in the retrospective attribution of cause to effect. The term for oath (mbiam) carries a mutable character and its meaning varies according to context, variously oath, ordeal and poison, similarly ambivalent features as the Mende hale (Jedrej 1976). In general, mbiam represents both an oath of innocence and a harmful charm. Mbiam is also be sworn as an oath of secrecy, as a pact to settle a dispute between rivals and to signify the spiritual purity of title holders. In a court case mbiam is sworn both to prove the veracity of evidence and as an ordeal to demonstrate innocence. In all these instances swearing mbiam, often a stone or a phial of salt water obtained from an oath specialist (abia mbiam), subjected the oath-taker to a year-long ordeal during which their premature death signified guilt. Oath-swearing is far more than a guarantee of veracity, therefore, it is also an ordeal through which oath-takers live or die. As Elizabeth Tonkin (2000) says, ordeals are divinatory practices and public performances - they are dramas of truth.

Public oaths have long been a deterrent used against criminals in Annang villages. Often village-wide oaths are sworn each year to bind the village to a pledge that they will not commit crime or associate with criminal gangs. One of the most significant popular responses to the crime-waves organised by the chiefs, for instance, illustrates the continued significance of mbiam in the Annang judicial system, and the practice of public oath-swearing to prevent theft. This is especially relevant in relation to the discourse on armed robbery, and in Ikot Akam, for example, villagers swear at the village council in August each year. Non-Christians swear on mbiam ikpa isong, the spirit of the village, and Christians swear on verses from the Bible that if they should steal, associate with thieves or join armed robbery gangs then they would be killed within six months. ${ }^{15}$

Vigilantes are also linked to a range of practices and ordeals that establish truth and character. In the Adat Ifang clan, on Obo market day wives prepare food, invite their parents and friends from their natal villages, and dance for the vigilantes. This is the ordeal of cleanliness (ukaj akee sana) and is held to test and celebrate the character of women married into the village. The type of food she produces proves that she works hard in the farm and has no reason to steal. The woman's innocence, cleanliness and beauty is designated by wearing a palm frond (eyei) on her right hand. She will sing 'mmenyong

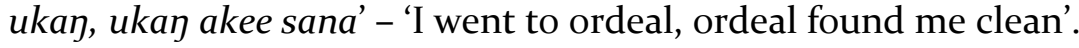

15. Nto Udofia Ekpuk Council Minutes, Ikot Akam, September 1989. 
The popular legitimacy of contemporary village vigilante groups is therefore derived from their role as an alternative judicial fora which, in turn, is linked to the use of a range of ordeals (ukay) in establishing guilt in cases of theft. In one instance in Ukanafun, a vigilante leader is himself an $u k a \eta$ ordeal specialist who investigates cases of theft with recourse to a tract from the Bible. The ordeal he administers is known as Bible Turn (Bible akanna). A key is placed inside the Bible and the ordeal-giver calls on the spirits of thieves in the Bible to identify the guilty party. The suspect undergoing the test holds the loop of the key which is suspending the Bible, and if proven guilty the Bible rotates three times. Simmons (1956: 225) reported this Bible-key divination (afia ukpohode) being used by children in Calabar. The key is placed in Acts 5 at the story of Ananias and Sapphira. Ananias and Sapphira embezzled money from a land sale and both died instantly when Paul challenged them and announced that they had tested the 'Spirit of the Lord.' Young men wrapped their bodies and carried them away to be buried. There are a number of reasons why this passage is especially resonant in an Annang context. 'Testing' (ndomo) is precisely the term used to undertake an Annang investigation by ordeal. The guilt of a thief tested by Bible akanna is therefore a test of the spirit of dead malevolent spirits. The fact that young men were responsible for the body is also significant for young vigilantes.

Youth associations and their vigilante patrols also routinely employ the broom doctor (ukaj ujaj) or what Simmons (1956: 224) reported as 'medicine-broom divination' (afia ifiet). Two brooms are held with their open bristles touching one another. In this position, with no link between them, the brooms should not be able to be fastened to anything or carry any weight. First at the feet and then seven times moving up the body the specialist touches the brooms against the body of the person undergoing the ordeal. The seventh touch reaches the neck at which point the brooms will either pass by on either side thereby releasing the person and revealing that they are speaking the truth or they form a firm bind and grip the person's neck which throttles and cuts into the skin at the larynx. This is the sign of deceit and guilt.

These are not unchanging 'traditional' ordeal practices. They appropriate concepts and symbols of justice from a range of registers. A recent innovation in ordeals used by Annang vigilantes, for example, mimics an ordeal witnessed in Igbo popular videos. The video 'Issakaba', a four-part drama highlighting the role of the Bakassi Boys, resonates with images of protective charms and truth-telling ordeals readily identified and appropriated by young men in nearby Annang villages. One ordeal seen in Issakaba videos is the use of a string of cowrie shells as a 'truth-telling belt'. In response to the upsurge in armed robberies since 1999, the vigilantes of Ikot Akpa Nkuk commissioned the manufacture and empowering of a similar object in 
August 2000, a rope (ikpo) known as the 'Champion Belt.' The vigilante's Champion Belt is used by tying it around the waist of a suspected thief who will confess to their actions, their accomplices and the items they have stolen. The belt not only compels suspects to speak the truth, therefore, but as with imagery of the malevolent ancestral force (ekpo ndem), it symbolically confirms their representation as a deviant and anti-social spirit.

The legitimacy of Annang vigilantism is linked to a number of further factors, many of which have not been discussed here but which have to do with the way in which vigilantism is embedded in practice in nightly routines, in relations between the generations, in bodily practice, in settling disputes, in sponsoring unemployed youth, and in scrutinizing contracts. Nevertheless it is important to stress that vigilantism above all is embedded in cultural understandings, both that it is grounded in concepts of personhood and also that it represents familiar ways of knowing and proving the truth.

\section{CONCLUSION: TACTICS, SPACE AND TIME}

The decentring of governance is one of the key features of globalization. Appadurai (2002: 24), for instance, examines these 'new geographies of governmentality' and argues that the appropriation of the means of governance by non-governmental groups has led to a crisis of 'redundancy' for the nation state. In the African context Mbembe has noted an abrupt collapse of notions of the post-colonial state's public good. Without rights or resources to re-distribute all that the post-colonial state has left to control are the forces of coercion (commandement). The resulting rise in the privatization of lawful violence is not an indicator of chaos, Mbembe states, but a sign of struggles aimed at establishing new forms of legitimate domination that restructure the existing formulas of authority (Mbembe 2001: 76).

The fracturing of the state on the one hand and the increasing significance of non-state actors on the other are especially pronounced features of contemporary Nigeria. The widespread mobilization of youth in civil disorder, for instance, provides a popular counternarrative to the legitimacy of the Nigerian nation state (Akinyele 2001; Ikelegbe 2001; Watts 2003; Agbu 2004). Here militant youth movements such as the O'odua People's Congress (OPC) in the West, the Ijaw Egbesu boys in the Niger Delta, the Bakassi Boys in the East, and the Arewa People's Congress (APC) in the North spearhead contemporary political contests between the politics of identity and citizenship. Each foregrounds contemporary social movements representing divergent imaginings of Nigeria: pro-Sharia in the north, ethnic nationalism in the west, and autonomous resource control in the oil-producing south. 
Neither the techniques of coercion, nor the dynamics of popular mobilization, however, capture the fine-grain of everyday ways of operating within the postcolony. In Africa, as John Peel has argued, political activity is the major mode of society's self-realization: 'It is conditioned not just by the structure of the state, but by attitudes and identities brought to the political arena by the members of local communities' (Peel 1983: 7). The contemporary 'politics of improvement' in Nigeria is defined by access to the state since this has become a precondition for doing business successfully. As competition for access to the state has intensified so people explore a diverse array of channels of access leading to a 'restless mobility' of people and their political and economic investments (Berry 1989: 55). This restless mobility is discussed here in the idea of a civic vigilance which points to the significance of internal imperatives and accountabilities that are employed in everyday interactions within the postcolony. The activities of the young vigilant citizens serve as a counterpoint to an analysis of cultural frameworks that emphasize instrumentalization, and contributes to work that shows how accountability assumes highly ambiguous, insurgent and surprising guises (Boyte 1992: 341).

The mode of vigilance outlined here concerning corruption, electoral patronage and crime is a particular feature of the politics of youth. It should be stressed that the petition-writers and vigilantes of Ikot Akpa Nkuk are often the same individuals. Their micro-political activities and 'invisible governances' (Hecht \& Simone 1994) appear to undermine the social cohesion necessary for the creation of meaningful institutions. They may, indeed, contribute to accounts of Nigeria that reveal 'ragged, unstable, perhaps ungovernable, spaces and analytics of government' (Watts 2003: 26). It is not surprising, however, that use of a Foucauldian theoretical model which employs the notion of governmentality and which incorporates a focus on governable objects, governable spaces and the creation of order through discourse, disciplines and technologies of government, is found to be ill-equipped to deal with the chaotic plurality of such localized manoeuvres (Watts 2003: 26).

In contrast, de Certeau's albeit underemployed concept of the 'tactic' seems especially attuned to this discussion. The way in which modes of governance are fractured give rise to a complex of localized strategizing that involves encompassing space and utilizing time. Youth groups are about encompassing constituencies - youth, lineage, village, minority as marginalized groups - and hence define spatial zones as enclosures of entitlement, inclusion and exclusion (Geschiere \& Nyamnjoh 2002). They also exploit various forms of temporal opportunity, in particular elections as moments of transition, and the nocturnal frontiers policed by vigilantes. Transitions from one political regime to another are privileged contexts not only for regimes but also for ordinary people to negotiate political inclusion and exclusion (Hansen \& Stepputat 2001: 26). Equally, it is important to locate vigilantism as a frontier phenomenon not only on the physical 
boundaries of state control, or urban no-go areas, but in temporal frontiers - of night and day (Abrahams 1996; 1998). The internal, cultural imperatives outlined here concerning the distributive expectations placed on patrons, and the deviant motivations inscribed on thieves map onto political responses characterized by fear and zeal (Worby 1998: 564). Tactics, therefore, are characterized by a watchful, opportunistic civic vigilance operating in a twilight between the predations and possibilities of the postcolony.

\section{ACKNOWLEDGEMENT}

This paper attempts to build on collaborative work with Charlie Gore to whom I am deeply indebted. It also draws on a paper I presented at the International Development Studies, Roskilde University. My thanks to all the participants and also to John Peel, Peter Geschiere, Karin Barber, Christian Lund, Jon Mitchell, Jeff Pratt and Nigel Eltringham for their comments. I should also like to record my thanks to the Economic and Social Research Council, the British Academy and the Nuffield Foundation for research funding.

\section{REFERENCES}

Abrahams, Ray (1996) 'Vigilantism: Order and disorder on the frontiers of the state', in Olivia, H. (ed) Inside and Outside the Law: Anthropological Studies of Authority and Ambiguity, pp. London: Routledge.

- (1998) Vigilant Citizens: Vigilantism and the State. Cambridge: Polity Press.

Agbu, Osita (2004) Ethnic Militias and the Threat to Democracy in Post-Transition Nigeria. Nordiska Afrikainstitutet.

Akinyele, R.T. (2001) 'Ethnic Militancy and National Stability in Nigeria: A Case Study of the Oodua People's Congress', African Affairs $100(401), 623-40$.

Amnesty International (2002) 'Nigeria: Vigilante violence in the south and south-east', AI INDEX: AFR 44/014/2002.

Appadurai, Arhun (2002) 'Deep Democracy: Urban Governmentality and the Horizon of Politics', Public Culture 14(1), $21-47$.

Austen, R.A. (1986) 'Criminals and the African cultural imagination: normative and deviant heroism in pre-colonial and modern narratives', Africa 56(4), 385-98.

Baker, B. (2002) 'When the Bakassi Boys Came: Eastern Nigeria Confronts Vigilantism', Journal of Contemporary African Studies 20(2), 223-44. 
Baker, Jonathan \& Poul Ove Pedersen (eds) (1992) The Rural Urban Interface in Africa: Expansion and Adaptation, Uppsala: The Scandinavian Institute of African Studies.

Banton, M. (1957) West African City: A Study of Tribal Life in Freetown. London: Oxford University Press for the International African Institute.

Barber, Karin (1982) 'Popular reactions to the petro-naira', Journal of Modern African Studies 20(3), 431-50.

Barkan, J. D. , M. L. McNulty \& M. A. O. Ayeni (1991) 'Hometown' Voluntary Associations, Local Development, and the Emergence of Civil Society in Western Nigeria', The Journal of Modern African Studies 29(3), 457-80.

Bayart, Jean-Francois (1993) The State in Africa: The Politics of the Belly. London: Longman.

Bayart, Jean-Francois, Stephen Ellis \& Beatrice Hibou (1999) The Criminalization of the State in Africa. Oxford: James Currey.

Berry, S. S. (1989) 'Social Institutions and Access to Resources', Africa $59,41-55$.

Boyte, Harry C. (1992) 'The Pragmatic Ends of Popular Politics', in Calhoun, C. (ed) Habermas and the Public Sphere, pp. 340-55. Massachusetts Institute of Technology.

Bucholtz, Mary (2002) 'Youth And Cultural Practice', Annual Review of Anthropology 31(1), 525.

Certeau, M. de (1984) The Practice of Everyday Life. Berkeley: University of California Press.

Chabal, Patrick \& Jean-Pascal Daloz (1999) Africa Works: The Political Instrumentalization of Disorder. London: James Currey.

Comaroff, John L. \& Jean Comaroff (2000) 'Introduction', in Comaroff, J.L. \& J. Comaroff (eds.) Civil Society and the Political Imagination in Africa: Critical Perspectives, pp. 1-43. Chicago, IL: The University of Chicago Press.

Cruise O'Brien, Donal B. (1996) 'A Lost Generation? Youth identity and state decay in West Africa', in Werbner, R. \& T. Ranger (eds.) Postcolonial Identities in Africa, pp. 55-74. London and New York: Zed Books.

Daum, C. (1992) L'immigration Ouest-Africaine en France: Une Dynamique Nouvelle dans la Vallée du Fleuve Sénégal? Paris: Institut Panos.

De Certeau, Michel (1984) The Practice of Everyday Life. Berkeley: University of California Press.

Diouf, M. (1996) 'Urban youth and Senegalese Politics: Dakar 19881994', Public Culture 8(2).

Durham, Deborah (2000) 'Youth and the Social Imagination in Africa: Introduction to Parts 1 and 2', Anthropological Quarterly 73(3), 113-20.

Ekeh, Peter (1975) 'Colonialism and Two Publics in Africa: A Theoretical Statement', Comparative Studies in Society and History 17(1), 91-112. 
Ferguson, J. (1997) 'Transnational Topographies of Power: Beyond 'the State' and 'Civil Society' in the Study of African Politics', Roskilde University Occasional Paper 19, 45-71.

Ferguson, J. \& A. Gupta (2002) 'Spatializing states: toward an ethnography of neoliberal governmentality', American Ethnologist 29(4), 981-1002.

Ferme, Mariane C. (2001) The underneath of things: violence, history, and the everyday in Sierra Leone. Berkeley, Calif.; London: University of California Press.

Fields, Karen (1982) 'Political Contingencies of Witchcraft in Colonial Central Africa: Culture and the State in Marxist Theory', Canadian Journal of African Studies 16(3), 567-93.

Forrest, Tom (1986) 'The Political Economy of Civil Rule and the Economic Crisis in Nigeria (1979-84)', Review of African Political Economy 35, 4-26.

Geschiere, P. \& J. Gugler (1998) 'The urban-rural connection: Changing issues of belonging and identification', Africa 68(3), 309-19.

Geschiere, Peter \& Francis Nyamnjoh (2002) 'Capitalism and Autochthony: The Seesaw of Mobility and Belonging', Public Culture 12(2), 423-52.

Gore, Charles \& David Pratten (2003) 'The Politics of Plunder: The Rhetorics of Order and Disorder in Southern Nigeria', African Affairs 102(407), 211-40.

Grillo, R. \& Bruno Riccio (2004) 'Translocal Development: ItalySenegal', Population, Space and Place 10, 99-111.

Gugler, J. (1971) 'Life in a Dual System: Eastern Nigerians in Town, 1961', Cahiers d'Etudes Africaines 11, 400-21.

- (1991) 'Life in a Dual System Revisited: Urban-Rural Ties in Enugu, Nigeria 1961-87', World Development 19(5), 399-409.

Gupta, A. (1995) 'Blurred boundaries: The discourse of corruption, the culture of politics, and the imagined state', American Ethnologist 22(2), 375-402.

Guyer, J. I. (1992) 'Representation without taxation - an essay on democracy in rural Nigeria, 1952-1990', African Studies Review 35(1), 41-80.

Hagberg, Sten (2002) 'Enough is Enough': an ethnography of the struggle against impunity in Burkina Faso', Journal of Modern African Studies 40(2), 217-46.

Hansen, Thomas Blom \& Finn Stepputat (2001) 'Introduction', in Hansen, T.B. \& F. Stepputat (eds.) States of Imagination, pp. 138. Durham: Duke University Press.

Harnischfeger, Johannes (2003) 'The Bakassi Boys: fighting crime in Nigeria', The Journal of Modern African Studies 41(1), 23-49.

Heald, S. (1986a) 'Witches and thieves: deviant motivations in Gisu society', Man 21(1), 65-78.

Hecht, David \& Maliqualim Simone (1994) Invisible Governance: the Art of African Micropolitics. New York: Autonomedia.

Herzfeld, Michael (1993) The social production of indifference: exploring the symbolic roots of Western bureaucracy. Chicago: University of Chicago Press. 
Honey, Rex \& Stanley Okafor (eds) (1998) Hometown Associations: Indigenous knowledge and development in Nigeria, London: Intermediate Technology.

Human Rights Watch (2002) 'Bakassi Boys: The Legitimization of Murder and Torture', Vol. 14 No 5. (A).

— (2003) 'The O'odua People's Congress: Fighting Violence with Violence', Vol. 15 No. 4.

Ikelegbe, A. (2001) 'The perverse manifestation of civil society: Evidence from Nigeria', Journal of Modern African Studies 39(1), 1-24.

Jedrej, M. C. (1976) 'Medicine, Fetish and Secret Society in a West African Culture', Africa 46, 247-57.

Kelsall, Tim (2003) 'Rituals of verification: indigenous and imported accountability in northern Tanzania', Africa 73(2), 174.

Lentz, Carola (1995) 'Youth associations in northern Ghana - unity for development', Africa 65(3), 395-429.

Lonsdale, J. (1986) 'Political Accountability in African History', in Chabal, P. (ed) Political Domination in Africa: Reflections on the Limits of Power, pp. 126-57. Cambridge: Cambridge University Press.

Lund, C. (2001) 'Precarious democratization and local dynamics in Niger: Micro-politics in Zinder', Development and Change 32(5), $845-69$.

Mbembe, Achille (1992) 'Provisional notes on the postcolony', Africa 62(1), 3-37.

- (2001) On the Postcolony. University of California.

McCall, John (1995) 'Rethinking ancestors in Africa', Africa 65(2), 25670.

McNulty, Michael L. \& F. Lawrence Mark (1996) 'Hometown Associations: Balancing local and extralocal interests in Nigerian communities', in Peter, B. \& D.M. Warren (eds.) Indigenous Organisations and Development, pp. 21-41. London: IT Publications.

Mitchell, Timothy (1991) 'The Limits of the State: beyond statist approaches and their critics', American Political Science Review 85(1), 77-96.

Momoh, Abubakar (200o) 'Youth Culture and Area Boys in Lagos', in Jega, A. (ed) Identity Transformation and Identity Politics under Structural Adjustment in Nigeria, pp. 181-203. Uppsala: Nordiska Afrikainstitutet in collaboration with the Centre for Research and Documentation, Kano.

Moore, Sally Falk (1996) 'Post-socialist micro-politics: Kilimanjaro, 1993', Africa 66(4), 587-606.

Mustapha, Abdul Raufu (2002) 'States, Predation \& Violence: Reconceptualizing Political Action and Political Community in Africa', paper presented at the paper presented at the Panel on State, Political Identity and Political Violence, 1oth General Assembly of CODESRIA, Kampala, Uganda, 8-12 December 2002. 
Newell, Stephanie (2001) "Paracolonial' Networks: Some Speculations on Local Readerships in Colonial West Africa', Interventions: International Journal of Post-colonial studies 3(3), 336-54.

Nolte, Insa (2004) 'Identity and violence: the politics of youth in IjebuRemo, Nigeria', The Journal of Modern African Studies 42(1), 6189.

Olivier de Sardan, J. P. (1999) 'A moral economy of corruption in Africa?' The Journal of Modern African Studies 37(1), 25-52.

Parkin, David (1966) 'Voluntary Associations as an Adaptive Institution', Man New Series 1(1), 90-95.

- (1969) Neighbours and Nationals in an African City Ward. London: Routledge and Kegan Paul.

Peel, J. D. Y. (1983) Ijeshas and Nigerians: The incorporation of a Yoruba Kingdom, 1880s-1970s. Cambridge: Cambridge University Press.

Picton, J. (1990) 'What's in a mask?' Journal of African Languages and Culture 2(2), 181-202.

Pratten, David (1997) 'Bamako Bound: The Social Organisation of Migration in Mali',

- (2000) Return to the Roots? Urban Networks, Rural Development and Power in Sudan. Edinburgh: University of Edinburgh.

- (forthcoming) The Man-Leopard Murder Mysteries: History and Society in Colonial Nigeria. Edinburgh University Press: International African Institute.

Reno, W. (2002) 'The Politics of Insurgency in Collapsing States', Development and Change 33(5), 837-58.

Rose, Nikolas (1999) Powers of freedom: reframing political thought. Cambridge: Cambridge University Press.

Schatzberg, Michael, G. (1993) 'Power, legitimacy and democratisation', Africa 63(4).

- (2002) Political legitimacy in Middle Africa : father, family, food. Bloomington, Ind.: Indiana University Press.

Simmons, D. C. (1956) 'Efik divination, ordeals and omens', Southwestern Journal of Anthropology 12(2), 223-28.

Smith, D. J. (2001a) 'Kinship and Corruption in Contemporary Nigeria', Ethnos 66(3), 344-64.

— (2004) 'The Bakassi Boys: Vigilantism, Violence and Political Imagination in Nigeria', Current Anthropology 19(3).

Smith, Daniel Jordan (2001b) 'Ritual Killing, 419, and Fast Wealth: Inequality and the Popular Imagination in Southeastern Nigeria', American Ethnologist 28(4), 803-26.

Smock, Audrey C. (1971) Ibo Politics: The Role of Ethnic Unions in Eastern Nigeria. Harvard: Harvard University Press.

Southall, A. W. (1975) 'Forms of Ethnic Linkage Between Town and Country', in David, P. (ed) Town and Country in Central and Eastern Africa, pp. 265-75. London: Oxford University Press for the International African Institute.

Tonkin, Elizabeth (2000) 'Autonomous Judges: African Ordeals as Dramas of Power', Ethnos: Journal of Anthropology 65(3), 36686. 
Trager, L. (1998) 'Home-town Linkages and Local Development in South-Western Nigeria. Whose Agenda? What Impact?' Africa 68(3), 360-82.

Udoma, Udo (1987) The Story of the Ibibio State Union. Ibadan: Spectrum Books.

Vaughan, Olufemi (1995) 'Assessing Grassroots Politics and Community Development in Nigeria', African Affairs 94, 501-18.

Watts, M. (2003) 'Development and governmentality', Singapore Journal of Tropical Geography 24(1), 6-34.

Wolpe, Howard E. (1974) Urban Politics in Nigeria: A Study of Port Harcourt. Berkeley: University of California.

Woods, D. (1994) 'Elites, Ethnicity, and Home Town Associations in the Cote- Divoire - an Historical-Analysis of State-Society Links', Africa 64(4), 465-83.

Worby, Eric (1998) 'Tyranny, parody, and ethnic polarity: Ritual engagements with the state in Northwestern Zimbabwe', Journal of Southern African Studies 24(3), 561-78.

Ya'u, Yunusa Zakari (2000) 'The Youth, Economic Crisis and Identity Transformation: The Case of the Yandaba in Kano', in Jega, A. (ed) Identity Transformation and Identity Politics under Structural Adjustment in Nigeria, pp. 161-8o. Uppsala: Nordiska Afrikainstitutet in collaboration with the Centre for Research and Documentation, Kano. 